\title{
ZABÓR PALACE IN THE LIGHT OF THE LATEST DISCOVERIES - INTERIOR OF THE ELEVATION USING SGRAFFITO TECHNOLOGY
}

\author{
Barbara BIELINIS-KOPEĆ ${ }^{1}$ \\ The Regional Office for the Protection of Monuments, Zielona Góra, Poland
}

\begin{abstract}
The property in Zabór from the fifteenth century belonged, among others, to families: von Tschammer, von Dyhrn, Montani, von Dünnewald, von Cosel and von SchönaichCarolath. The testimony of its magnificence is a palace built by Count Johann Heinrich von Dünnewald in the 4th quarter of the seventeenth century, in the type of early baroque French residence, which, after 1745 was expanded in a magnificent baroque residence by Count Friedrich August von Cosel. In 2014 during the renovation of the monument one encountered a mannerist sgraffito, and facades of the old previously unknown buildings, were decorated with it, dating back probably to the early seventeenth century, which sheds a new light on the history of the monument and its construction phases.
\end{abstract}

Keywords: aroque residence in Zabór, sgraffito decoration on the facade

\section{THE HISTORY OF ZABÓR AND ITS OWNERS}

The first mention of the village dates back to $1306^{2}$. In 1453 Zabór belonged to the family von Tschammer, who was growing gradually their goods to Milsko in 1482 and $\mathrm{Laz}$ - in 1553. However, in 1585 the family von Tschammer went bankrupt. In 1588 Zabór was in possession of Melchior von Dyhrn, and then of his son Christoph. After him, the goods were inherited by his son Joachim Friedrich. Then, after his death in 1646, the property was inherited by his daughter

\footnotetext{
${ }^{1}$ Corresponding author: The Regional Office for the Protection of Monuments in Zielona Góra, Kopernik st 1,65-001 Zielona Góra, lwkz@o2.pl.tel. +48603124295.
} 
Countess von Gartenberg. In about half of the seventeenth century, the property in Zabór was bought by Baron Maximilian von Montani. But soon after his death, in the years 1663-1665, one introduced the management of goods in Zabór, which was held by Georg Ernst Pfister, official of Nowa Sól Domanial Office. Then, the property was inherited by the imperial court adviser Baron Joachim Friedrich von Blumenthal, due to overdue salaries and settlements with the imperial court [1]. Already in 1669, a year before the death of Baron von Blumenthal, Zabór was in the hands of Cavalry General Johann Heinrich von Dünnewald [5]. In 1675 von Dünnewald received the title of Count of the Reich, his emolument were Zabór, Tarnawa and Czarna. In the following years, until his death in 1691, Dünnewald gradually expanded the property, including Milsko, Łaz, Droszków, Upper and Lower Tarnawa, Pyrnik, Jeziory and Kolsko. The heirs of Count von Dünnewald were his sons, Franz and Ludwig. Since 1694, after the death of his brother, the owner of the property became Count of the Reich Ludwig von Dünnewald [1]. Ludwig from the beginning led a lavish lifestyle, which, combined with mismanagement of estates and many lost processes with people, resulted in the takeover of the debtor's assets immediately after his death. The property, after the childless death of Ludwig, was taken by Emperor Charles VI, who in 1719 sold it to the Great Chancellor of the court Count of the Reich Philipp Ludwig von Sinzendorf. Then, in 1726 Zabór was bought by the imperial chamberlain Franz Anton Count von Pachta, and from 1744 the property belonged to Count Friedrich August von Cosel, the son of the king of Poland and Saxon Elector Augustus the Strong and Countess von Cosel. Count Cosel died in 1770 following a two-year earlier duel, in which he was seriously wounded. His son and heir Gustav Ernst von Cosel took goods after coming of age in 1780 and within a year he squandered them. Administration of the assets was taken over by Count von Schlabrendorf, who sold it in 1783 to Prince Friedrich Hans Carl von Schönaich, Lord of Siedlisko and Bytom. After his death in 1791 Zabór fell into hands of Prince Christian Ernst Augustus Ferdinand von Schönaich. After his childless death in 1805 the property was taken over by another member of the family - Prince Friedrich Wilhelm Carl von Schönaich, in whose possession it remained until 1843. After him, in the years 1843-1893, the owner of Zabór became Prince Ferdinand von Schönaich, and then his son Prince Georg von Schönaich. In the years 1922-1945 palace in Zabór was the residence of Hermina von SchönaichCarolath, née von Reuss, the widow of Emperor Wilhelm II. After World War II the property was nationalized and one set up here the staff training centre of Association "Peasant Self-Help". In the 50s of the twentieth century in the palace functioned tuberculosis preventorium. Then, in the 80s of the twentieth century, it housed a National Tuberculosis Sanatorium. Today, the palace is home to the Treatment Centre for Children and Youth. 


\section{PALACE IN ZABÓR}

The first mention of the castle in Zabór comes from 1608 when its then owner Christoph von Dyhrn was treacherously murdered by Baron Carl von Zedlitz. Most likely, however, the owners headquarter of the property was established earlier when it was in the hands of the family von Tschammer, who, from here, managed its vast possessions since the second half of the sixteenth century. The idea of the existence of an older, wooden residence at the place of the current palace was immortalized in literature and was shared by both the German and Polish researchers. It was to be a wooden building that burned down and in its place in the 70s of seventeenth century, or at the end of this century, Count of the Reich Heinrich Johann von Dünnewald built a palace [7]. The immediate reason for the creation of a new brick residence, close to the old (wooden building destroyed by fire), was marriage to Countess von Limburg. Researchers also agree that the final shape of the palace in Zabór was created in the reconstruction and expansion of the residence made by Count Friedrich August von Cosel after a fire in 1745 . The fire destroyed the interior of the palace, and completely destroyed the upper floor. The palace was rebuilt and enriched by two towers, which housed staircases. In the basement, on the axis of the main wing, one incorporated an oval hall, acting as a representative hall. The interior of the palace was also transformed [1]. Count von Cosel contributed to the baroque mansion new fashionable patterns, shaping the design of its interior in the spirit of Rococo. His role commemorates placed in the tympanum on the front elevation cartouche with the initials FAC (Friedrich August Cosel). In the last phase of the redevelopment of the residence, which was in the nineteenth century, when it found itself in the hands of the family von Schönaich-Carolath, one built a floor wing - gallery topped by a terrace with a balustrade $[6]^{2}$ with passing gate, decorated with a cartouche with coats of arms, one of which belonged to the family von SchönaichCarolath. From the courtyard were introduced cloisters, arcade opening on three sides. At the same time the palace façades were given the decorations in conventions of nineteenth-century historicism.

Palace in Zabór, in primary stroma, is a building of 4th quarter of seventeenth century, representing the type of early baroque mansion in France. For its present shape severely affected redevelopment in the 2 nd half of the eighteenth century,

\footnotetext{
${ }^{2}$ It was built on the site of an older wing that we know of, among others, from the iconographic forms (views of the palace in Zabór from approx. half of eighteenth century in the work F. B. Werner, Topographie Sue Compendium Silesiae, and $2^{\text {nd }}$ half of XIX c. in album of A. Duncker, Die ländlichen Wohnsitze, Schlösser und Residenzen der ritterschaftlichen Grundbesitzer in der preussischen Monarchie). The architectural analysis showed no angular binding of walls of the endangered gallery with the wings of the palace, which speaks for its later erecting. In addition crest von Schönaich-Carolath, above the passing gate points to its rise in the period of belonging to this family.
} 
when the palace was transformed into a magnificent baroque residence, which splendor was added by a large garden, shaped in the style of the French trend. In the nineteenth century the building was enriched with elements maintained in the mainstream of historicism, not blurring signs of older eras. In accordance with the spirit of the times, one also transformed the baroque garden into the park of a landscape nature (Figure 1).

So marked and settled in the literature timing frames and monument transformations phases require verification to the discovery of sgraffito decoration on the north elevation of the west wing of the palace during the renovation of the monument in 2014.

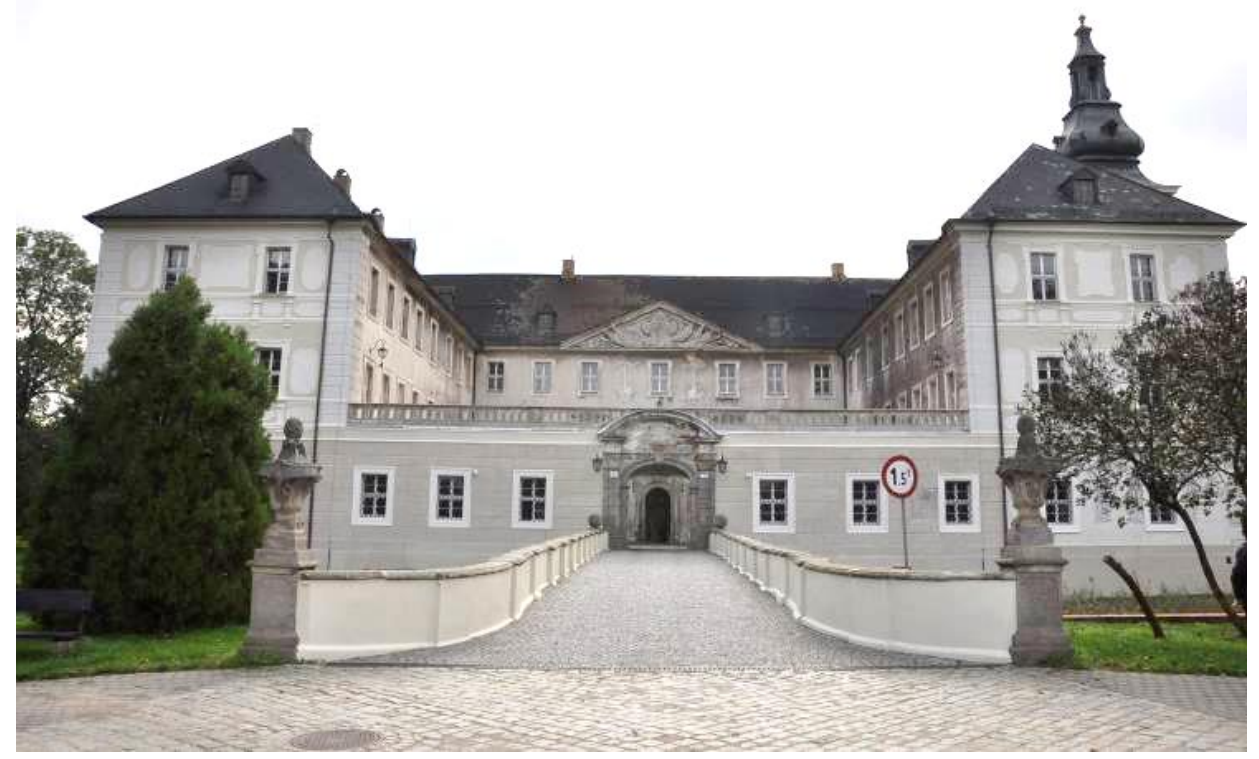

Fig. 1. Palace in Zabór. View from the North

\section{CONSERVATION AND RESTORATION WORKS}

Research and conservation and restoration works of sgraffito decorations on the north elevation of the western wing of the palace in Zabór were carried out in summer 2014, based on the work program developed by M. Kozarzewski and M. Koczorowska, art conservators, by a team of restorers under the direction of $\mathrm{M}$. Koczorowski.

The works were undertaken in intervention mode while running the renovation of the palace facade, one revealed under the top layers of plaster fragments of older decoration, made in sgraffito technique. Their actions were dictated by the 
exceptional value of this discovery and the very bad state of sgraffito preservation. It survived in approx. $60 \%$ on the first floor- and approx. $40 \%$ on the second floor of the facade. As it was estimated, loosening from the ground occurred at approx. $80 \%$ of the total preserved decoration. The cause of the damage was primarily mechanical damage, preceding the elevation covering with another layer of plaster, probably in connection with its rebuilding in the 2 nd half of the eighteenth century when, in order to improve the adhesion of the substrate, one made cuts with a sharp instrument in the original layer with sgraffito decoration. On the conservation status of sgraffito, external exposure also had an influence on the North, undergoing constant change in temperature and humidity, atmospheric rainfall and winds, which caused numerous destruction of the original substance. The technique of decoration (drawing carved in whitewash) facilitated the ingress of rainwater into the deeper structure of the plaster, which catalysed the process of destruction of mortars and whitewash [2].

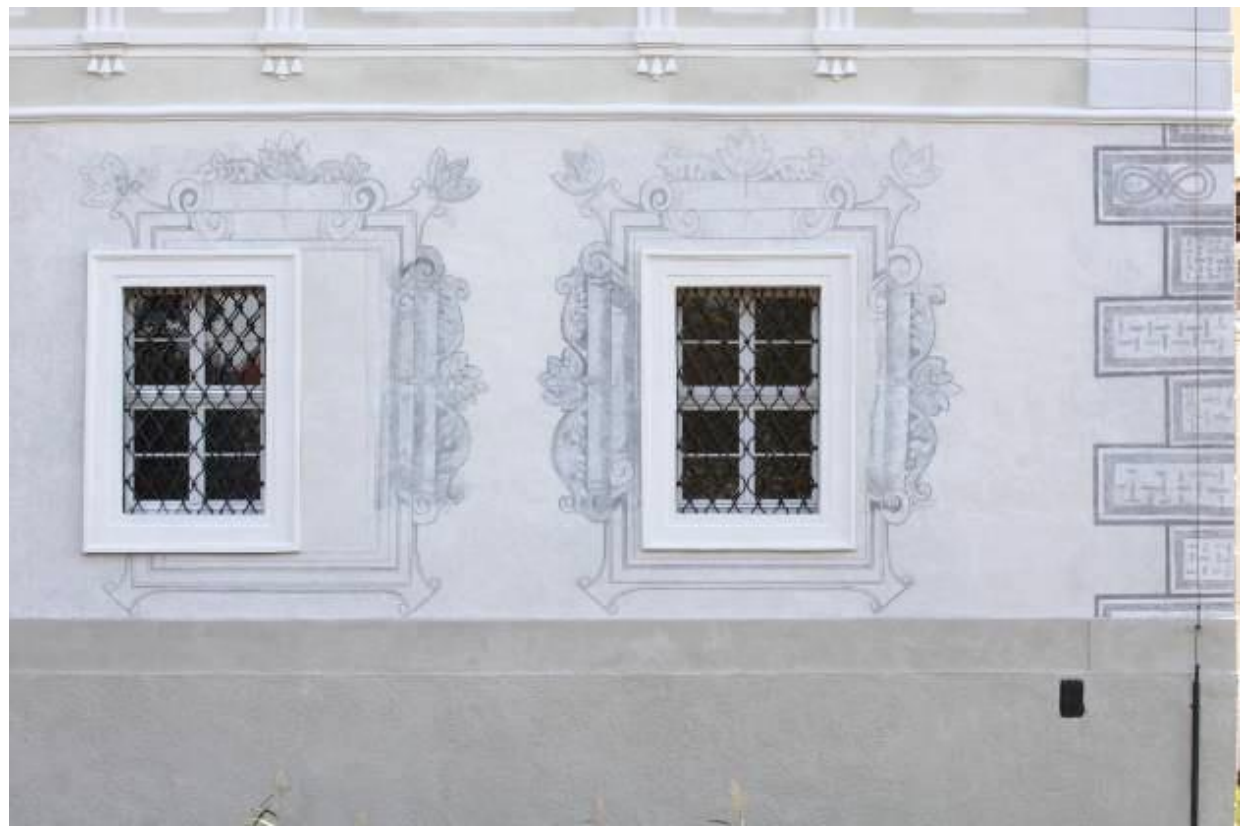

Fig. 2. Sgraffiti on the northern wall of the western wing of the palace in Zabór, after the work of conservation and restoration

During the tests it was established that the decoration was made on a substrate that is a brick wall in the technique of sgraffito two-tier, wherein the arriccio (i. e. the bottom layer of plaster) is a coarse sand-lime mortar, and intonaco (surface layer) - a thin layer of lime mortar, coloured in the mass of charcoal in batches for decorating. The whole was covered with lime whitewash in which one carved and cut ornamental decoration. Decoration centred around window openings, 
creating their decorative frames, and on the corners, in the form of rustication. The whole of discovered relics were examined and documented. At the same time it was decided to undergo conservation and restoration of fragments of decoration preserved in the ground floor part, where they occurred to a greater extent and it was possible to show them clearly (Fig. 2).

Before proceeding to works of conservation and restoration, one carried out photographic, descriptive, and drawing documentation of discovered decoration relics. The work included, among others: removal of surface contamination and repainting, preservation of the layers of original plaster, execution of reinforcements in blistering and loosening, preservation of the layer of original mortar with decoration, plaster completion in plaster technology of lime-sand and lime-sand with extra charcoal, the execution of dot retouches within the whitewash, the execution of reconstruction of composition by sgraffito in places where the original decorations couldn't be preserved, colour integration, preservation of decoration surfaces. As a result of the conducting works of conservation and restoration, one manage to comprehend a mannerist fragment of design of the palace facade in Zabór, bearing witness to its rich history and stages of transformation, which could form the basis for further study of the monument.

\section{ANALOGIES FOR SGRAFFITO DECORATION ON THE ELEVATION OF PALACE IN ZABÓR - DATING}

Authors of conservation and restoration works pointed out the analogies of sgraffito decoration on the facade of the palace in Zabór with the decoration of the facade of the palace in Broniszów, dating sgraffito in Zabór for the beginning of the seventeenth century [2]. Analogies can be seen both in the art, ornamentation and the arrangement of the composition. In both cases, one used the technique of two-tier sgraffito, where arriccio is a lime-sand mortar, and intonaco - a layer of lime mortar colored in the mass of charcoal, covered with lime whitewash. In both monuments, the windows were inscribed in elaborate frames, integrated symmetrically. Window openings are framed by rectangular, linear frames, topped, and covered on both sides with an ornament decoration of scrollwork and the motive of acanthus tendril and a single five-fingered leaves. Their corners were leaded diagonally, using scrollwork ornament and threefingered leaf motif. Decoration also appears in the extreme parts of the facade, in the form of boni, framing their surface. Ornamental decoration in both buildings is concentrated around window openings (Fig. 3), and the corners of the facade were embraced by rustication.

In the light of this discovery raises the question of the time of creation and the initiator erected in Zabór brick headquarters of the mannerist design of elevation. 


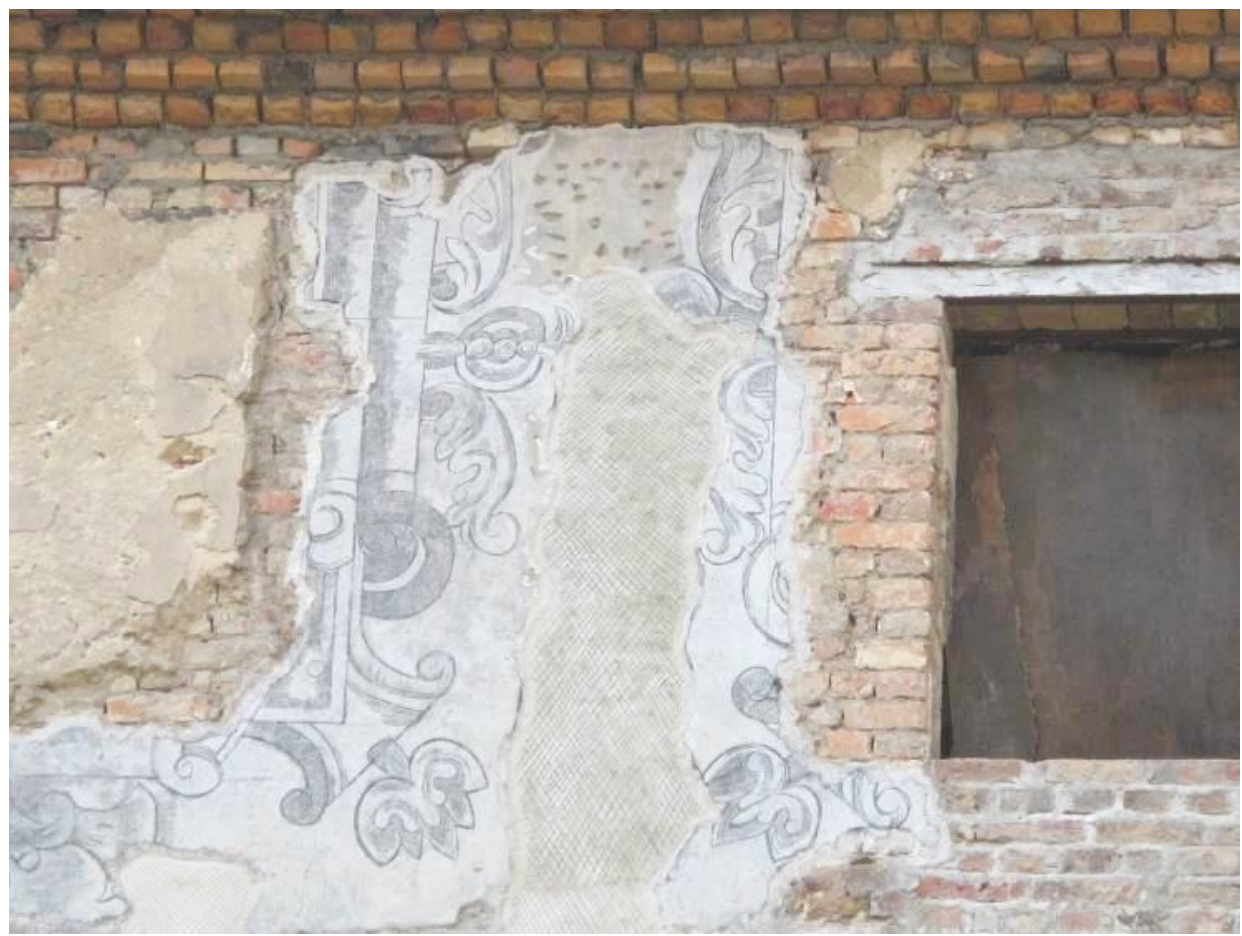

Fig. 3. Sgraffito on the facade of the palace in Broniszów

Researchers have so far accepted that the palace was built in the 4 quarter of the seventeenth century on the site of an older, wooden residence which was burned down. There is no doubt, however, that the building, which preceded the creation of the Dünnewald palace was made of brick, while the sgraffito decorating its facades date back to the beginning of the seventeenth century. This confirms the time of design origin of the palace facade in Broniszów (there is a date preserved on the tower - 1606) and stylistic analysis of decoration of both buildings, i. e. mannerist ornamentation based on scrollwork ornament. One focused their attention on this period, trying to assign a rise of building to a particular property owner. An important clue was the information that in 1604 Christoph von Dyhrn married Anna von Stentzsch [1], which could have contributed to the construction of the new headquarters, where a young couple was supposed to live $\mathrm{e}^{3}$. We also know that already in 1608 , Christoph von Dyhrn was murdered at his castle in Zabór [1]. The castle, first mentioned in the sources, is probably the building, which traces were encountered during the renovation. There is no doubt that the history of the palace in Zabór requires taking into account its earlier phases, i. e.

\footnotetext{
${ }^{3}$ Also, the erection of the palace by Count von Dünnewald was to take place immediately before marrying his first wife Countess von Limburg.
} 
stone castle, which remains are to be found in the structure of the western wing of the palace, taking the time of erecting the buildings, decorated in sgraffito technique, using mannerist ornamentation, for the beginning of the seventeenth century. Traces of the building became apparent not only in a form of mentioned decoration but also in a clear difference in the structure of the walls of two renovated wings of the palace. After forging the loosening plaster plinth in the socle party, one could see the differences in technique and building material, i. e. the western wing was built using erratic boulders and bricks, while the east wing - only bricks. It should also be recalled that monographer of monument E. Lukas, analyzing its architecture, drew attention to the style backwardness of palace built by Count von Dünnewald, for which explanation could be found, in Lukas's opinion, in the necessity to adapt the new residence to an existing building at this location [6]. This all seems to confirm the proposed thesis that in the early seventeenth century, one built in Zabór brick headquarters, with facades decorated with sgraffito, which initiator could be the then owner of the estate, Christoph von Dyhrn.

\section{REFERENCES}

1. Förster A.: Geschichtliches von Dörfen des Grünberger Kreises. Aus den besten vorhandenen Quellen..., Grünberg 1905.

2. Koczorowska M., Kadłubowska-Boruchalska J.: Dokumentacja prac konserwatorskich $i$ restauratorskich dekoracji sgraffitowych na elewacji pótnocnej skrzydła zachodniego pałacu w Zaborze, woj. lubuskie, Warszawa 2014, maszynopis w archiwum Wojewódzkiego Urzędu Ochrony Zabytków w Zielonej Górze, sygn.13614.

3. Kowalski St.: Zabytki województwa zielonogórskiego, Zielona Góra 1987.

4. Kowalski St.: Zabytki architektury województwa lubuskiego, Zielona Góra, Zielona Góra 2010.

5. Kuczer J.: Od glorii do upadku. Osadnictwo szlachty tytularnej na Ślasku po wojnie trzydziestoletniej na przykładzie rodziny hrabiów von Dünnewald (1669-1718), Studia Śląskie, 68, (2009) 93-116.

6. Lukas E.: Pałac $w$ Zaborze, Szczecin 1966, m-pis w archiwum Wojewódzkiego Urzędu Ochrony Zabytków w Zielonej Górze sygn. 72.

7. Lutsch H.: Verzeichnis der Kunstdenkmäler der Provinz Schlesien, Bd. III, Die Kunstdenkmäler des Reg.-Bezirks Liegnitz, Breslau 1891.

8. Neuling H.: Schlesiens Kirchorte und ihre kirchlichen Stiftungen bis zum Ausgang des Mittelalters, Breslau 1902

9. Zamki, dwory i pałace województwa lubuskiego, redaktor B. Bielinis-Kopeć, Wojewódzki Urząd Ochrony Zabytków w Zielonej Górze, Zielona Góra 2008. 


\section{PAŁAC W ZABORZE W ŚWIETLE NAJNOWSZYCH ODKRYĆ - DEKORACJA ELEWACJI W TECHNICE SGRAFFITA}

Streszczenie

Zachowany do dnia dzisiejszego w Zaborze pałac, wzniesiony został przez hr. Heinricha Johanna von Dünnewald w 4 ćwierci XVII wieku w typie wczesnobarokowych rezydencji francuskich. Po 1745 roku został rozbudowany w okazałą barokową rezydencję przez hr. Friedricha Augusta von Cosel. Niewielkie zmiany wprowadzono w XIX wieku, gdy należał do rodu von Schönaich-Carolath. W literaturze przedmiotu utrwalił się pogląd, że von Dünnewald wzniósł pałac na miejscu starszej, drewnianej siedziby, która została spalona. Wymaga on weryfikacji w związku $\mathrm{z}$ dokonanym w 2014 roku odkryciem. W trakcie remontu elewacji natrafiono na manierystyczne sgraffita, którymi ozdobione były elewacje starszej, nieznanej dotąd murowanej budowli. Sgraffita z Zaboru są analogiczne pod względem kompozycji, ornamentyki oraz techniki do wystroju elewacji pałacu w Broniszowie, datowanego na 1606 roku, co rzuca nowe światło na dzieje pałacu w Zaborze i fazy jego budowy. Należy przyjąć, że już w początkach XVII wieku wzniesiono tu murowaną siedzibę. Inicjatorem budowy był zapewne Christoph von Dyhrn, który w 1604 roku pojął za żonę Anne von Stentzsch, zaś cztery lata później został zamordowany na swoim zamku w Zaborze. Wspomniany po raz pierwszy w źródłach w 1608 roku zamek jest zapewne budowlą, na której ślady natrafiono w trakcie remontu. Nie ulega więc wątpliwości, iż historia pałacu w Zaborze wymaga uwzględniania jego starszej fazy tj. murowanego zamku, którego pozostałości należy szukać w strukturze skrzydła zachodniego pałacu, przyjmując czas powstania budowli, dekorowanej $\mathrm{W}$ technice sgraffita, $\mathrm{z}$ wykorzystaniem manierystycznej ornamentyki, na początek XVII wieku.

Słowa kluczowe: barokowy pałac w Zaborze, manierystyczna dekoracja elewacji w technice sgraffita

Editor received the manuscript: 21.02.2015 
PUSTA 